\title{
The Role of Experiential Learning and Volunteer Motivation in Service- Learning Business Course in Higher Education
}

\author{
Liz C. Wang \\ West Chester University \\ Lori R. Fuller \\ West Chester University
}

Although educators suggest integrating Kolb's four stages of experiential learning cycle in servicelearning (SL) pedagogy, no higher education research has demonstrated how to create experiential activities for each stage. Little is known about the impacts of student volunteer motivation and individual learning strategies. This research examines the effects of undergraduates' perceptions of experiential learning and volunteer motivation in a business SL course on student learning outcomes. Two field studies were conducted. Volunteer motivation and experiential learning perception influence student learning outcomes. To capitalize on the benefits of SL pedagogy, a high-level experiential learning course is a must.

Keywords: experiential learning, service-learning pedagogy, student learning outcomes, volunteer motivation, marketing teaching method

\section{INTRODUCTION}

The American Association of Community Colleges (AACC) defines service learning (SL) as the combination of community service and classroom instruction, with a focus on critical, reflective thinking as well as personal and civic responsibility (Gottlieb and Gibson 2006). Numerous universities and colleges advocate SL pedagogy as it is believed to broaden educational programs with more practical and experiential learning (Godfrey \& Berry, 2005). More importantly, it embodies a purpose to strengthen civic responsibility in business education (Geringer, Stratemeyer, Canton, and Rice, 2009). Distinct from other experiential learning approaches, SL pedagogyhas unique contributions towards develop students' civic responsibility.

Experiential learning encompasses a variety of pedagogical approaches, including real-life cases (LeCair \& Stottinger, 1999), service learning (Petkus, 2000), internships, and simulations (GonzalezPadron \& Ferguson, 2015). SL pedagogy is one of many experiential learning approaches that are rooted in Kolb's (1984) experiential learning theory (Young, Caudill, \& William, 2008). Kolb (1984) suggests that experiential learning occurs through a sequence of four stages: concrete experience, reflective observation, abstract conceptualization, and active experimentation. Although educators suggest integrating Kolb's experiential learning cycle for SL pedagogy (e.g., Petkus 2000), no research in 
business education literature in higher education has demonstrated how to create learning activities for each stage.

Wang and Calvano (2018) argue that a SL course must be well designed to activate and stimulate the four stages of Kolb's (1984) experiential learning cycle in order to exert positive influences on student learning outcomes. Several marketing education studies provide suggestions on how to design SL courses within marketing education, but none have integrated Kolb's experiential learning theory. For example, Geringer et al. (2009) recommend the following six steps of service-learning assignments in marketing courses: (1) introduction to the importance of community service and service-learning, (2) relevance of marketing principles in nonprofit organizations, (3) service assignment, (4) on-going discussion, (5) reflect with written report, and (6) debriefing. Cadwallader, Atwong and Lebard (2013) suggest that students may adopt a nonprofit organization to review its current marketing communication program, or they may prepare a marketing plan for a nonprofit organization. Although SL is rooted in Kolb's experiential learning theory, no existing SL research in business literature in higher education has conducted and demonstrated the application of Kolb's four stages of learning to create impactful experiential learning. To fill this void, the first objective of this study aims to demonstrate how to design experiential activities and assignments that activate all four stages of Kolb's (1984) experiential learning cycle for a SL project in a Consumer Behavior marketing course in the higher education.

Extensive research suggests many benefits of SL pedagogy on student learning outcomes, such as academic outcomes, personal growth, career development, and civic responsibility (e.g. Jacoby, 2014). However, several studies found undesirable effects of "mandatory volunteerism" from SL courses. Volunteering implies free choice (Beehr, LeGro, Porter, Bowling, and Swader, 2010). When students are "forced" to provide services to community partners in a SL course, they are regarded as "mandatory volunteers" (Stukas, Snyder, \& Clary, 1999). Such requirements may engender psychological reactance (Brehm \& Brehm, 1981) that may affect one's volunteer motivation. In the context of SL courses, when students do not volunteer using their own free will, their intention to volunteer may decrease (Stukas et al. 1999). Likewise, Beehr et al. (2010) found that required student volunteers in SL courses had lower levels of university commitment and satisfaction than non-required volunteers. Despite the existing research that raises concerns of students' volunteer motivation in SL courses, little is known about the impacts of volunteer motivation on student learning outcomes. In addition, even when students work on the same SL project, they may perceive different levels of experiential learning due to individual preferences in their learning strategy (Young et al. 2008). Some students may perceive the SL pedagogy as having higher levels of experiential learning, but others may not.

To discover any undesirable effects resulting from SL courses, the objective of Study\#1 is to investigate the effects of students' perceptions of experiential learning and volunteer motivation in a SL course on their learning outcomes. Furthermore, Study\#2 was conducted to compare these constructs between SL classes and non-SL classes in the same business Marketing course in higher education. While educators are devoted to promoting SL pedagogy at higher education, it is critical for them to minimize undesirable effects resulting from SL pedagogy.

\section{LITERATURE REVIEW AND RESEARCH HYPOTHESES}

\section{Service Learning and Learning Outcomes}

Service-Learning (SL) pedagogy has several distinct characteristics from traditional teaching methods. SL courses usually engage students in hands-on service with a community partner by conducting community-based projects or volunteering to work for the community partner. SL pedagogy

relates the service project to course content to help student academic learning. Students conduct reflections to discover the meanings of their SL experiences. Importantly, SL promotes civic values to students when they become involved with local communities.

Business educators recognize the potential of SL to improve traditional education methods (Yorio \& Ye, 2011; Godfrey et al., 2005). SL pedagogy exposes students to different stakeholder groups, organizational types and societal issues that can create a breadth of knowledge in business education 
(Godfrey et al, 2005). It also prepares business students to be more ethical and socially responsible (Berry \& Workman, 2007). Kline and Athaide (2004) report that students responded favorably in terms of academic learning, communication, and team skills. Hagnebuch (2006) found that students responded positively on understanding the subject matter, theory application, and career development. The distinct benefit of using SL pedagogy is widening the student's lens on the world beyond their major and profession and encouraging them to be well-rounded and engaged citizens (Lester, Tomkovikc, Wells, Fluncker, \& Kickul, 2005).

Geringer et al. (2009) summarized four key benefits of student learning outcomes from SL pedagogy: academic learning, career development, personal growth, and civic responsibility. It offers students the opportunity to apply and integrate classroom theories in real-life settings as they work on community projects (Geringer et al., 2009). By interacting with community partners in SL, students have opportunities to practice and improve their professional and social skills (Petkus, 2000), gain new contacts that extend their career network (Berry \& Workman, 2007), and access potential employment opportunities (Geringer et al., 2009). Personal growth involves learning about one's feelings, biases, strengths and weaknesses as well as obtaining social skills, such as leadership, teamwork and effective communication. Civic responsibility involves students' social awareness, commitment to community needs and the obligations of citizenship (Wang \& Calvano, 2018).

\section{Experiential Learning}

Kolb (1984) defines experiential learning as a process whereby knowledge is created through the transformation of experience. Approaches to experiential learning combine traditional fact-based knowledge acquisition along with active involvement, interaction with others, observations and hands-on work during the learning process (Young et al., 2008). The immediacy and closeness of the learning experience provides students with opportunities to make connections that might not emerge from lecturebased traditional techniques. Experiential learning encompasses a variety of pedagogical approaches, including real-life cases (LeCair \& Stottinger, 1999), service learning (Petkus, 2000), internships, and simulations (Gonzalez-Padron \& Ferguson, 2015). Service-learning pedagogy is distinguished from other experiential approaches by its intentions to equally benefit community partners as well as students (Furco, 1996). In SL courses, students are required to provide services for the community partners. As a result, the community partners benefit from the student's efforts while the students enhance their learning experience by applying what has been taught to a real-world setting (Geringer et al., 2009).

Kolb (1984) claims that experiential learning occurs through a sequence of four stages: concrete experience, reflective observation, abstract conceptualization, and active experimentation. Concrete experience involves knowledge acquisition through sensory perceptions, emotional engagement, and direct practical experiences with the world. Abstract conceptualization is knowledge acquisition through which students transform their experiences from a concrete to a symbolic system. This stage involves indepth thinking to integrate theories and concepts into the overall learning process (Young et al., 2008). Reflective observation involves making connections across experiences as well as intentional consideration of an experience in light of a particular objective (Hatcher \& Bringle, 2000). This stage creates meaning and transforms the students' perceptions of the experience. Active experimentation focuses on "doing" to integrate theories, concepts, or processes with real-world activities and to apply knowledge and test concepts in practice (Young et al., 2008). Wang and Calvano (2018) suggest that SL pedagogy must embrace these four stages of the experiential learning cycle. At each stage, an instructor should incorporate experiential activities that stimulate the student to engage in deep meaningful learning.

Dewey (1933) noted that experience in and of itself is not always educative. Additionally, Bacon and Stewart (2006) note that projects can be a hit-or-miss method of learning. Thus, students may perceive or respond to the same service-learning course differently. For example, Young et al. (2008) suggest that a student learning strategy may influence one's perceived levels of experiential learning. Additionaly, they found that experiential learning activities that incorporate all stages of the learning cycle were positively related to a deep approach to learning; but were negatively related to a surface approach to learning. Students who concentrated on the underlying purpose and meaning of the learning are classified as using 
a deep approach to learning. In contrast, students with surface approach to learning focus on facts and ideas to memorize. In the context of service-learning, Wang and Calvano (2018) found that student learning outcomes are highly and significantly associated with the student's perception of the four learning stages in SL courses. Specifically, when students perceived higher levels of the four stages of the experiential learning cycle, they tend to have more positive learning outcomes such as academic learning, career development, personal growth, and civic responsibility. Accordingly, we suggest that students who perceive a high level of experiential learning from the SL courses may have a more favorable SL learning outcome, and vice versa.

H1: Students who perceive a high level of experiential learning will report more favorable SL learning outcomes than those who perceive a low level of experiential learning.

H1 a: Students who perceive a high level of experiential learning will report more favorable academic learning than those who perceive a low level of experiential learning.

$\boldsymbol{H} 1$ b: Students who perceive a high level of experiential learning will report more favorable career development than those who perceive a low level of experiential learning.

H1 c: Students who perceive a high level of experiential learning will report more favorable personal growth than those who perceive a low level of experiential learning.

H1 d: Students who perceive a high level of experiential learning will report more favorable civic responsibility than those who perceive a low level of experiential learning.

\section{Volunteerism Motivation}

Volunteerism is when individuals lend assistance to others in need (Krebs \& Miller, 1985). Volunteering provides the foundation for numerous nonprofit programs and it is regarded as a very important activity in society (Tomkovick, Lester, Flunker, \& Wells, 2008). For example, in the U.S., approximately $30 \%$ of Americans, about 77.3 million, volunteered in 2018 . The worth of this volunteer service was estimated at $\$ 167$ billion. To prepare college students to be well-rounded citizens, numerous colleges and universities have integrated service-learning pedagogy in traditional curricula (Garver, Divine, \& Spralls, 2009).

Why do people volunteer? Volunteers are motivated by a variety of needs. For example, volunteers may need to feel useful/productive (Bussell \& Forbes, 2002), need social interaction (Wymer, 2003), need status (Peterson, 2004), need to make oneself more marketable, or have strong personal concern for a cause (Peterson, 2004; Bussell \& Forbes, 2002). Garver et al. (2009) found that students preferred to volunteer when the activity was related to their interests, majors, and friends and had relatively low time commitment.

Volunteerism is usually non-obligatory involvement (Penner, 2004). It also implies free choice (Beehr et al., 2010). However, when students are required to provide services in SL courses, such a requirement makes volunteerism become "mandatory" or "required." According to psychological reactance (Brehm \& Brehm, 1981), it suggests that limiting an individual's freedom to act may lead to a desire to reestablish that freedom; which can be accomplished by disparaging the forced activity and refusing to perform it once the mandate had been lifted. For example, in a study of a total of 371 business undergraduates who were required to enroll in a service-learning course, Stukas et al. (1999) found that mandatory volunteerism has a greater negative impact on future intent to volunteer for those who feel less inclined to volunteer of their own free will. Likewise, Piliavin and Callero (1991) reported that blood donors who gave blood for the first time under coercion expressed lower intentions to continue donating in the future than those who were not coerced.

Mandatory requirements may impact volunteer motivation in undesirable ways. In a survey of undergraduate students, Beehr et al., (2010) compared non-required volunteers with required volunteers 
(enrolled in SL courses) on their motivation, university commitment, and satisfaction with their university. They found that students who were required to volunteer in service-learning courses reported more extrinsic motivation as well as lower levels of commitment and satisfaction with their university than their counterparts. Such "required volunteerism" exerts negative effects on student commitment and satisfaction with their university. In addition, these required volunteers from a SL course might be motivated for external rewards, e.g. their course grade. If mandated students begin to perceive that they help only when it is required or rewarded, then their intentions to freely engage in volunteer service in the future may be reduced (Clary, Snyder, \& Stukas, 1998).

Motivation is a compelling force of volunteering. Students may vary on their reactions to mandatory or required volunteerism. In SL courses, some students may not feel particularly "forced" into volunteerism because they are intrinsically motivated to volunteer (Stukas et al., 1999). On the other hand, others have a less positive attitude toward volunteerism in SL courses and may feel "forced" or "required" to volunteer for external motivation, such as grades or graduation requirements (Stukas et al., 1999). For example, in research about blood donation in Iran, Maghsudlu and Nasizadeh (2011) found that internal motives, instead of external motives, are the main driver to donate blood. Internal motives are believed to exert stronger volunteer motivation than external motives. Thus, when students are forced to provide services for external motives, their volunteer motivation may be weaker than those who are intrinsically motivated. On the flip side, when students don't feel "required" or "mandated" to volunteer in SL courses, their motivation should be stronger or greater than their counterparts.

Burns (2010) used the Volunteer Functions Inventory scale (VFI) to measure the extent or strength of volunteer motivation of students enrolled in SL courses. He found when students perceive servicelearning activities as beneficial, they tend to increase their volunteer motivation. Clary, Snyder, Ridge, Copeland, Stukas, Haugen, Miene, and Diener (1998) propose six motivational functions served by volunteerism and developed the Volunteer Functions Inventory scale (VFI). VFI includes six sub dimensions: values, understanding, career, protective, social, and enhancement. According to Clary et al. (1998), the values function refers to the opportunities that volunteerism provides for individuals to express values related to altruistic and humanitarian concerns for others. The understanding function of volunteering refers to opportunities for new learning experiences and the chance to exercise knowledge, skills, and abilities that might otherwise go unpracticed. The social function reflects motivations concerning relationships with others. Volunteering may offer opportunities to be with one's friends or to engage in an activity viewed favorably by important others. The career function is concerned with careerrelated benefits that may be obtained from participation in volunteer work. The protective function motivations involve processes associated with the functioning of the ego. Whereas the enhancement function involves a motivational process that centers on the ego's growth and development, including positive strivings of the ego.

Based on these findings, some students may decrease their volunteer motivation due to their psychological reactance against mandatory volunteerism in SL courses. Those students with decreasing or low volunteer motivation may perceive less favorable outcomes from SL experiences. On the other hand, when students don't feel forced to volunteer in SL courses, they don't respond to mandatory volunteerism with psychological reactance and could be intrinsically motivated to volunteer. Their volunteer motivation is not affected by mandatory volunteerism in SL courses. Compared to the group of students with decreasing or low volunteer motivation, these students may have a higher level of volunteer motivation and then may perceive more favorable outcomes from SL pedagogy. Thus, the hypotheses regarding volunteer motivation are as follows.

H2: Students who have a high level of volunteer motivation will report more favorable SL learning outcomes than those who have a low level of volunteer motivation.

H2 a: Students who have a high level of volunteer motivation will report more favorable academic learning than those who have a low level of volunteer motivation. 
$\boldsymbol{H} 2$ b: Students who have a high level of volunteer motivation will report more favorable career development than those who have a low level of volunteer motivation.

H2 $c$ : Students who have a high level of volunteer motivation will report more favorable personal growth than those who have a low level of volunteer motivation.

$\boldsymbol{H} 2$ d: Students who have a high level of volunteer motivation will report more favorable civic responsibility than those who have a low level of volunteer motivation.

\section{STUDY\#1: RESEARCH METHODS AND RESULTS}

\section{Field Study}

A field study was conducted in the Marketing Department of a mid-size regional public university in the Mid-Atlantic section of the United States. Participants were undergraduates enrolled in a Consumer Behavior course with a mandatory service-learning project. All students in this class were required to work as a team on a service-learning project for a nonprofit community partner during a semester. The same instructor (Professor A) taught this marketing course and followed the guidelines below to select a SL partner and to design a SL course.

\section{Selection of an SL Partner}

Several criteria are used to select a SL partner. First, SL partners are nonprofit organizations from the local community. Second, the marketing objectives of its SL project are relevant to the learning objectives in the Consumer Behavior course. Third, students have access to the consumers that the SL organization is targeting in this project. Lastly, the SL clients must agree to fulfill the following responsibilities: (1) visit and brief the class about the SL organization and goals of the SL project, (2) offer opportunities allowing students to interact with them, to visit their facilities, and/or try their services/products, (3) to listen to all students' marketing presentations and offer feedback, and (4) select the best team from the presentation competition and honor each team member with a winning certificate. Professor A found the SL partners through the university's Office of Service-Learning \& Volunteer Programs or directly reached out to the local nonprofit organization. Over two semesters, this SL course worked with two nonprofit organizations whose marketing objectives focused on understanding their consumer needs and developing marketing plans.

\section{Design of Experiential Learning Activities in SL Course}

This course has two components. The first component is the traditional fact-based knowledge acquisition for relevant marketing or consumer behavior theories and concepts. The second part focused on the service-learning project where students applied marketing or consumer behavior knowledge to conduct consumer research and develop a marketing plan for the SL organization. For each of the SL project, the key experiential learning activities on each stage are the same but the content was adapted to fit the context of the specific SL project.

Experiential learning is a process whereby knowledge is created through the transformation of experiences from learning activities. Wang and Calvano (2018) suggest that the design of experiential learning activities should be created and incorporated with all four stages of Kolb's (1984) theory involved in experiencing, thinking, acting and reflecting. Accordingly, Table 1 illustrates how the instructor designed the key experiential learning activities for the four stages in Kolb's theory. Each stage of Kolb's learning cycle has distinct objectives in the student's learning process. For each stage, experiential learning activities are created to achieve those objectives. As a result, student knowledge is created through experiential learning activities at each stage. For example, concrete experience focuses on

direct practical experience with the real world. To achieve this goal, several real-world activities in business settings are created for students. The examples of the experiential learning activities in this stage include SL client briefing, marketing presentation competition, or field trips that allow students to bridge 
the gap between academic learning and the real world. Students may transform the experiences from these activities to gain knowledge about the marketing consulting process including social and/or professional skills for the business world.

On the abstract conceptualization stage, the activities are designed to involve the students' in-depth thinking to integrate theories into the overall learning process or the application in the real world. Specifically, the instructor designs in-class-exercises that allow students applying marketing concepts into the context of the SL organization. Additionally, the instructor creates marketing plan outlines that illustrate a symbolic system. By using the marketing plan outlines with key components, students may not only learn "how to" work on each component step-by-step but also see how these components relate or integrate. From the experiences in applying concepts into the SL context, students may understand the symbolic system better and learn to apply it in different business settings in the future.

The stage of active experimentation focuses on doing. Hence, the experiential activities at this stage involve students creating marketing materials, conducting online research, or developing a marketing plan. From doing these activities, students may acquire knowledge on the process of "how-to" and develop skills to do it. As an example, when students are required to create videos for social media, they learn the process and skills from developing ideas to posting videos on platforms. Reflection is a critical stage in which students make connections across experiences and make sense out of the learning process for themselves. A reflection journal assignment with two questions was designed toward this goal. For example, while thinking of the impact of the SL project, students may gain awareness of social needs in their local community or find out what contributions they could offer. At the end, students may create relevant or personal meanings of their project to themselves.

TABLE 1

EXPERIENTIAL LEARNING DESIGN IN THE SL CONSUMER BEHAVIOR COURSE

\begin{tabular}{|c|c|c|}
\hline $\begin{array}{l}\text { Kolb's } 4 \text { Stages in } \\
\text { Experiential } \\
\text { Learning Cycles }\end{array}$ & $\begin{array}{c}\text { List of Experiential Learning Activities } \\
\text { Activities offer experiences or stimulate } \\
\text { students to engage in deep meaningful } \\
\text { learning. }\end{array}$ & $\begin{array}{l}\text { Student Knowledge Created } \\
\text { What knowledge is created } \\
\text { through the transformation of } \\
\text { experience from the activities? }\end{array}$ \\
\hline $\begin{array}{l}\text { Concrete } \\
\text { experience } \\
\text { involves } \\
\text { knowledge } \\
\text { acquisition } \\
\text { through sensory } \\
\text { perceptions, } \\
\text { emotional } \\
\text { engagement, and } \\
\text { direct practical } \\
\text { experiences with } \\
\text { the world. } \\
\text { (experiencing) }\end{array}$ & $\begin{array}{l}\text { Activate a real-world SL project - Students } \\
\text { work in a team to offer marketing consulting } \\
\text { services for a nonprofit community partner. } \\
\text { Assignment - Each student writes a journal } \\
\text { about the background of the SL organization } \\
\text { before the client's visit. } \\
\text { Client Briefing - The SL client visits the class } \\
\text { to introduce their organization and marketing } \\
\text { objectives that the class can help with. } \\
\text { More Interaction Opportunities } \\
\text { Students have opportunities to interact with } \\
\text { the SL clients in the classroom or via emails. } \\
\text { Student field trips to visit the SL organization } \\
\text { or facilities. Students have opportunities to } \\
\text { observe or try the client's services or } \\
\text { products. } \\
\text { SL Project Presentations - The SL client } \\
\text { listens to each group's presentation and asks } \\
\text { questions. The SL clients offer feedback } \\
\text { about presentations. } \\
\text { The SL clients must choose the best team and } \\
\text { honor them with winning certificates. }\end{array}$ & $\begin{array}{l}\text { Allow student to bridge the gap } \\
\text { between academic learning and } \\
\text { the real world. } \\
\text { Gain direct practical } \\
\text { experiences to work with a real- } \\
\text { life client. } \\
\text { Acquire team, social or } \\
\text { interpersonal skills to work with } \\
\text { others. } \\
\text { Gain an understanding of the } \\
\text { marketing consulting process } \\
\text { and jobs. } \\
\text { Gain an understanding of the } \\
\text { nature of competition in the } \\
\text { business world. }\end{array}$ \\
\hline
\end{tabular}




\begin{tabular}{|c|c|c|}
\hline $\begin{array}{l}\text { Kolb's } 4 \text { Stages in } \\
\text { Experiential } \\
\text { Learning Cycles }\end{array}$ & $\begin{array}{c}\text { List of Experiential Learning Activities } \\
\text { Activities offer experiences or stimulate } \\
\text { students to engage in deep meaningful } \\
\text { learning. }\end{array}$ & $\begin{array}{l}\text { Student Knowledge Created } \\
\text { What knowledge is created } \\
\text { through the transformation of } \\
\text { experience from the activities? }\end{array}$ \\
\hline $\begin{array}{l}\text { Abstract } \\
\text { conceptualization } \\
\text { is knowledge } \\
\text { acquisition } \\
\text { through which } \\
\text { students transform } \\
\text { their experiences } \\
\text { from a concrete to } \\
\text { a symbolic } \\
\text { system. This stage } \\
\text { involves in-depth } \\
\text { thinking to } \\
\text { integrate theories } \\
\text { and concepts into } \\
\text { the overall } \\
\text { learning process. } \\
\text { (thinking) }\end{array}$ & $\begin{array}{l}\text { Lecture \& Exam - Use lectures to teach } \\
\text { marketing concepts and theories, and to } \\
\text { describe the framework of the marketing plan. } \\
\text { Use exam(s) to test student basic knowledge } \\
\text { of the theories, concepts or framework. } \\
\text { Use of in-class exercise (ICEs) \& class } \\
\text { discussions - Design ICEs to help students } \\
\text { apply theories in the SL context. } \\
\text { Use class discussions to help students } \\
\text { engaged in-depth thinking. } \\
\text { Use marketing plan outlines -Offer Marketing } \\
\text { Plan Outlines for students to develop their } \\
\text { marketing plan. }\end{array}$ & $\begin{array}{l}\text { Students transform experiences } \\
\text { to a symbolic system. } \\
\text { Students acquire basic } \\
\text { knowledge of marketing } \\
\text { theories, concepts, and } \\
\text { theoretical frameworks. } \\
\text { Gain knowledge on the } \\
\text { applications of theories into a } \\
\text { real context. } \\
\text { Students learn how to integrate } \\
\text { theories and concepts with a real } \\
\text { project. } \\
\text { Enhance understanding of a } \\
\text { Marketing Plan. }\end{array}$ \\
\hline $\begin{array}{l}\text { Active } \\
\text { experimentation } \\
\text { focuses on } \\
\text { "doing" to } \\
\text { integrate theories, } \\
\text { concepts, or } \\
\text { processes with } \\
\text { real-world } \\
\text { activities and to } \\
\text { apply knowledge } \\
\text { and test concepts } \\
\text { in practice. } \\
\text { (acting) }\end{array}$ & $\begin{array}{l}\text { Conduct Research - Each student must } \\
\text { conduct an in-depth interview with 2-3 target } \\
\text { consumers. Each group must conduct } \\
\text { Qualtrics online research and analyze research } \\
\text { data. } \\
\text { Develop a Marketing Plan - Each group must } \\
\text { use evidence-based research to develop a } \\
\text { marketing plan. } \\
\text { Create Marketing Materials - Each group } \\
\text { must create some marketing materials, such as } \\
\text { flyers, videos, or posts for social media. } \\
\text { Present - Each student must make a } \\
\text { presentation to the SL clients. }\end{array}$ & $\begin{array}{l}\text { Put students learning into } \\
\text { practice for real-world partners. } \\
\text { Acquire knowledge or skills } \\
\text { from the processes of doing, } \\
\text { creating, or developing. For } \\
\text { example, students gain skills to } \\
\text { use Qualtrics or to create and } \\
\text { edit videos. }\end{array}$ \\
\hline $\begin{array}{l}\text { Reflective } \\
\text { observation } \\
\text { involves making } \\
\text { connections } \\
\text { across } \\
\text { experiences as } \\
\text { well as intentional } \\
\text { consideration of } \\
\text { an experience in } \\
\text { light of particular } \\
\text { objective. } \\
\text { (reflecting) }\end{array}$ & $\begin{array}{l}\text { Reflection Assignment- } \\
\text { Students must write a journal to address the } \\
\text { two questions below. } \\
\text { What impact(s) do you think our SL project } \\
\text { may have on our community? } \\
\text { What is one thing that you can take away } \\
\text { from the SL project that can help you with } \\
\text { your future career within the field of } \\
\text { Marketing? }\end{array}$ & $\begin{array}{l}\text { Students create relevant or } \\
\text { personal meanings of this } \\
\text { project to themselves. } \\
\text { Increase awareness of social } \\
\text { issues and needs in the local } \\
\text { community. } \\
\text { Gain an understanding of } \\
\text { personal strengths/weaknesses } \\
\text { or career interests. } \\
\text { Enhance understanding of civic } \\
\text { responsibilities. }\end{array}$ \\
\hline
\end{tabular}




\section{Sample}

At the end of the semester, all the students enrolled in these SL classes were invited to fill out an online survey about their service-learning experiences. A total of 133 undergraduates voluntarily participated in this research. About $70 \%$ of the respondents were $21-22$ years old, $56 \%$ were females, and $91 \%$ were marketing majors. Approximately $35 \%$ were juniors and $62 \%$ were seniors.

\section{Measures}

This study adopted multiple-item measures to provide a more representative assessment of each measure's domain (Bringle \& Hatcher, 2000). The measurement scales included the four stages of experiential learning (Young et al., 2008), four service-learning outcomes (Geringer et al., 2009), the volunteer function inventory (Clary et al., 1998), and demographic variables. The scale validity of each construct had been tested in previous research. Except for demographic variables, all questions used seven-point Likert scales. In Young et al.'s (2008) study, there are 12 questions that represent the four subscales or stages of experiential learning: concrete experience, reflective observation, abstract conceptualization, and active experiment. As shown in Table 2 the Cronbach alpha coefficient is 962 for the combined Experiential Learning stages and alphas range from .929 to .868 for the four sub-scales. We used Clary et al.'s (1998) Volunteer Function Inventory (VFI) to measure volunteer motivation. The VFI includes 30 questions that represent six sub-dimensions: values, career, understanding, social, protective, and enhancement. Similar to Clary et al. (1998, p. 1525) we split the high/low VFI by the scale mean. Table 2 shows a coefficient alpha of .913 for the combined six dimensions of the VFI; with alphas ranging from .922 to .839 for the six sub-scales. A total of 20 questions were used to measure servicelearning outcomes for the four subscales: academic learning, career-related, personal growth, and civic responsibility (Geringer et al., 2009). The results reveal a Cronbach alpha coefficient of .93 for the combined service-learning outcomes and alphas ranging from .897 to .807 for the four sub-scales. All Cronbach alpha coefficients were higher than the minimum requirement of 0.7 (Nunnally, 1978).

TABLE 2

\section{MEASURES \& QUESTIONS ITEMS}

\begin{tabular}{|c|c|}
\hline Measures/Subscales/Question Items (Study\#1/Study\#2) & $\begin{array}{l}\text { Cronbach's } \alpha \\
\text { Coefficient }\end{array}$ \\
\hline \multicolumn{2}{|l|}{ Experiential Learning Stages (4 Dimensions Combined $\alpha=.962 / .951$ ) } \\
\hline Sub Scale: Concrete Experience & $0.868 / 0.901$ \\
\hline \multicolumn{2}{|l|}{$\begin{array}{l}\text { This activity provided me with a direct practical experience to help understand the } \\
\text { course concepts. }\end{array}$} \\
\hline \multicolumn{2}{|l|}{$\begin{array}{l}\text { This activity gave me a concrete experience that helped me learn the class } \\
\text { material. }\end{array}$} \\
\hline \multicolumn{2}{|l|}{ This activ } \\
\hline Sub Scale: Reflective Observation & $0.884 / 0.864$ \\
\hline \multicolumn{2}{|l|}{ This activity assisted me in thinking about what the course material really means to me. } \\
\hline \multicolumn{2}{|l|}{ This activity helped me relate my personal experiences to the content of this course. } \\
\hline \multicolumn{2}{|l|}{ This activity aided me in connecting the course content with things I learned in the past. } \\
\hline Sub Scale: Abstract Conceptualization & $0.929 / 0.865$ \\
\hline \multicolumn{2}{|l|}{$\begin{array}{l}\text { This activity required me to think how to correctly use the terms and concepts } \\
\text { from this class. }\end{array}$} \\
\hline This activity caused me to think how the class concepts were inter-related. & \\
\hline This activity made me organize the class concepts into a meaningful format. & \\
\hline
\end{tabular}




\begin{tabular}{|c|c|}
\hline Measures/Subscales/Question Items (Study\#1/Study\#2) & $\begin{array}{l}\text { Cronbach's } \alpha \\
\text { Coefficient }\end{array}$ \\
\hline Sub Scale: Active Experimentation & $0.876 / 0.863$ \\
\hline This activity made it possible for me to try things out for myself. & \\
\hline $\begin{array}{l}\text { This activity permitted me to actively test my ideas of how the course material can } \\
\text { be applied. }\end{array}$ & \\
\hline This activity allowed me to experiment with the course concepts in order to & \\
\hline \multicolumn{2}{|l|}{ Volunteer Functions Inventory (VFI) (6 Dimensions Combined $\alpha=.913 / .933$ ) } \\
\hline Sub Scale: Protective & $0.922 / 0.898$ \\
\hline No matter how bad I've been feeling, volunteering helps me to forget about it. & \\
\hline By volunteering I feel less lonely. & \\
\hline $\begin{array}{l}\text { Doing volunteer work relieves me of some of the guilt over being more fortunate } \\
\text { than others. }\end{array}$ & \\
\hline Volunteering helps me work through my own personal problems. & \\
\hline Volunteering is a good escape from my own troubles. & \\
\hline Sub Scale: Values & $0.904 / 0.919$ \\
\hline I am concerned about those less fortunate than myself. & \\
\hline I am genuinely concerned about the particular group I am serving. & \\
\hline I feel compassion toward people in need. & \\
\hline I feel it is important to help others. & \\
\hline I can do something for a cause that is important to me. & \\
\hline Sub Scale: Career & $0.839 / 880$ \\
\hline $\begin{array}{l}\text { Volunteering can help me to get my foot in the door at a place where I would like } \\
\text { to work. }\end{array}$ & \\
\hline I can make new contacts that might help my business or career. & \\
\hline Volunteering allows me to explore different career options. & \\
\hline Volunteering will help me to succeed in my chosen profession. & \\
\hline Volunteering experience will look good on my resume. & \\
\hline Sub Scale: Social & $0.911 / 0.875$ \\
\hline My friends volunteer. & \\
\hline People I'm close to want me to volunteer. & \\
\hline People I know share an interest in community service. & \\
\hline Others with whom I am close place a high value on community service. & \\
\hline Volunteering is an important activity to the people I know best. & \\
\hline Sub Scale: Understanding & $0.855 / 0.887$ \\
\hline I can learn more about the cause for which I am working. & \\
\hline Volunteering allows me to gain a new perspective on things. & \\
\hline Volunteering lets me learn things through direct, hands on experience. & \\
\hline I can learn how to deal with a variety of people. & \\
\hline I can explore my own strengths. & \\
\hline Sub Scale: Enhancement & $0.882 / 0.89$ \\
\hline Volunteering makes me feel important. & \\
\hline Volunteering increases my self-esteem. & \\
\hline Volunteering makes me feel needed. & \\
\hline Volunteering makes me feel better about myself. & \\
\hline
\end{tabular}




\begin{tabular}{|l|l|l|}
\hline \multicolumn{2}{|l|}{ Measures/Subscales/Question Items (Study\#1/Study\#2) } & $\begin{array}{c}\text { Cronbach's } \boldsymbol{\alpha} \\
\text { Coefficient }\end{array}$ \\
\hline Volunteering is a way to make new friends. & \\
\hline Student Learning Outcomes (4 Dimensions Combined $\boldsymbol{\alpha}=\mathbf{. 9 3 / . 9 4 5 )}$ & \\
\hline Sub Scale: Career Related Outcomes & $0.807 / 0.76$ \\
\hline$\quad$ Made me more aware of possible career opportunities. & \\
\hline & Made me more aware of benefits of volunteering. & \\
\hline Made me more marketable upon graduation. & $0.897 / 0.895$ \\
\hline Sub Scale: Academic Outcomes & \\
\hline & Better understanding of course content. & \\
\hline & Should be used in more business classes. & \\
\hline & Enhanced my leadership skills. & \\
\hline & Enhanced my ability to communicate my ideas. & \\
\hline & Showed me how marketing is used in everyday life. & $0.891 / 0.886$ \\
\hline & Learned more than using a traditional project. & \\
\hline Sub Scale: Personal Development & \\
\hline & Expand my understanding of people in general. & \\
\hline & Enabled me to learn more about diversity. & \\
\hline & Helped me define my strengths and weaknesses. & \\
\hline & I feel more comfortable working with other cultures after completing the project. & \\
\hline & Helped me become aware of personal biases. & \\
\hline & Had a positive effect on my self-esteem. & \\
\hline Sub Scale: Civic Responsibility & \\
\hline & Showed me how I can become more involved. & \\
\hline & Made me more aware of needs in my community. & \\
\hline & I will be more likely to volunteer at the community agency of the project. & \\
\hline & Feel that I can make a contribution to the organization. & \\
\hline
\end{tabular}

We conducted a factor analysis with Oblimin rotations with a preselected 3-factor solution to check discriminate validity. Table 3 shows results of the factors where $76.24 \%$ of the total variance is explained. Each subscale was loaded to its construct with a factor loading higher than 0.7 (Hair, Black, Babin and Anderson, 2010). Further, confirmatory factor analysis using AMOS was used to assess both the convergent and discriminant validity of measures. Fit statistics of the measurement model were $\chi^{2}{ }_{(72)}=187.318, \mathrm{p}=0.000 ; \mathrm{CMIN} / \mathrm{DF}=2.6<3 ; \mathrm{CFI}=.941>0.9 ; \mathrm{TLI}=.926>0.9 ; \mathrm{RMSEA}=110$. Except for RMSEA, all other metrics were higher than the recommended thresholds (Hair et al. 2010). The model was considered a good fit (Hair et al. 2010). All the indicators load strongly on their corresponding factors and all were statistically significant $(\mathrm{p}<.01)$. All the composite reliabilities of the three constructs in Table 4 were above 0.7 (Fornell \& Larcker 1981). Each AVE (average variance extracted) exceeded the threshold of 0.50 and was higher than its MSV. Thus, the convergent and discriminant validity of these measures are considered adequate. 
TABLE 3

FACTOR ANALYSIS FOR MEASURES AND SUBSCALES

\begin{tabular}{|c|c|c|c|}
\hline \multirow[b]{3}{*}{ Subscale dimensions } & \multicolumn{3}{|l|}{ Factor Loading } \\
\hline & SL Outcomes & $\begin{array}{l}\text { Volunteer } \\
\text { Functions } \\
\text { Inventory }\end{array}$ & $\begin{array}{l}\text { Experiential } \\
\text { Learning }\end{array}$ \\
\hline & 1 & 2 & 3 \\
\hline academic & 0.951 & & \\
\hline career & 0.852 & & \\
\hline personal & 0.797 & & \\
\hline civic & 0.774 & & \\
\hline VFI-enhancement & & 0.927 & \\
\hline VFI-understanding & & 0.853 & \\
\hline VFI-protective & & 0.796 & \\
\hline VFI-career & & 0.789 & \\
\hline VFI-social & & 0.731 & \\
\hline VFI-value & & 0.727 & \\
\hline concrete & & & 0.972 \\
\hline abstract & & & 0.904 \\
\hline active & & & 0.901 \\
\hline reflect & & & 0.82 \\
\hline
\end{tabular}

Extraction Method: Maximum Likelihood.

Rotation Method: Oblimin with Kaiser Normalization.

Total Extracted Variance: $76.240 \%$

TABLE 4

CONVERGENT AND DISCRIMINANT VALIDITY ANALYSIS

\begin{tabular}{|l|l|l|l|l|l|l|}
\hline & CR & AVE & MSV & $\begin{array}{l}\text { Volunteer } \\
\text { Motivation }\end{array}$ & SL Outcomes & $\begin{array}{l}\text { Experiential } \\
\text { Learning }\end{array}$ \\
\hline $\begin{array}{l}\text { Volunteer } \\
\text { Motivation }\end{array}$ & 0.918 & 0.652 & 0.429 & 0.807 & & \\
\hline $\begin{array}{l}\text { SL } \\
\text { Outcomes }\end{array}$ & 0.933 & 0.778 & 0.507 & 0.655 & 0.882 & \\
\hline $\begin{array}{l}\text { Experiential } \\
\text { Learning }\end{array}$ & 0.963 & 0.865 & 0.507 & 0.474 & 0.712 & 0.930 \\
\hline
\end{tabular}

\section{Research Results}

We used the mean of the four subscales of experiential learning to represent a respondent's experiential learning level. Similarly, we used the average of the six subscales of VFI to represent a respondent's volunteer motivation value. We ran ANOVA analyses to check if there were any differences between the two community partners on students' perceived experiential learning and volunteer motivation. The results reveal no significant differences between the two community partners on experiential learning $\left(\mathrm{F}_{(1,132)}=0.102, \mathrm{p}<0.750\right)$, and on volunteer motivation $\left(\mathrm{F}_{(1,132)}=0.570, \mathrm{p}<0.452\right)$. Accordingly, both data sets were combined. Furthermore, the high and low experiential learning groups were separated by using the mean of total experiential learning values from all respondents (mean=5.86). 
Consistent with Clay et al.'s (1998) study, the high/low volunteer motivation groups were created by using the average of the total volunteer motivation values from all respondents (mean=5.48).

TABLE 5

ANOVA ANALYSIS RESULTS

\begin{tabular}{|c|c|c|c|c|c|c|c|c|}
\hline \multirow{2}{*}{$\begin{array}{l}\text { Independent } \\
\text { Variable }\end{array}$} & \multicolumn{2}{|c|}{$\begin{array}{l}\text { Academic Learning } \\
\text { Outcome (a) }\end{array}$} & \multicolumn{2}{|c|}{ Career Outcome (b) } & \multicolumn{2}{|c|}{ Personal Growth (c) } & \multicolumn{2}{|c|}{$\begin{array}{c}\text { Civic } \\
\text { Responsibility(d) }\end{array}$} \\
\hline & F-value & $\mathrm{p}<$ & F-value & $\mathrm{p}<$ & F-value & $\mathrm{p}<$ & F-value & $\mathrm{p}<$ \\
\hline $\begin{array}{l}\text { Model } \\
\text { F-Value (3, } \\
\text { 129) }\end{array}$ & 43.999 & $0.000 *$ & 24.281 & $.000 *$ & 22.065 & $.000 *$ & 22.184 & $0.000^{*}$ \\
\hline $\begin{array}{l}\text { Experiential } \\
\text { Learning } \\
\text { (Low/High) } \\
\text { H1 }\end{array}$ & 59.824 & $0.000 *$ & 29.639 & $0.000 *$ & 22.103 & $0.000 *$ & 17.481 & $0.000 *$ \\
\hline $\begin{array}{l}\text { Volunteer } \\
\text { Motivation } \\
\text { (Low/High) } \\
\text { H2 }\end{array}$ & 21.973 & $0.000 *$ & 15.401 & $0.000 *$ & 18.013 & $0.000 *$ & 23.132 & $0.000 *$ \\
\hline $\begin{array}{l}\text { Experiential } \\
\text { Learning X } \\
\text { Volunteer } \\
\text { Motivation }\end{array}$ & 5.558 & $0.020 * *$ & 0.785 & 0.377 & 0.165 & 0.685 & 2.334 & 0.129 \\
\hline R-Squared & 0.505 & & 0.361 & & 0.339 & & 0.34 & \\
\hline
\end{tabular}

* Significant at the level of $0.01 ; * *$ Significant at the level of 0.05

ANOVAs were used to test each research hypothesis. To test $\mathrm{H} 1 \mathrm{a}$ and $\mathrm{H} 2 \mathrm{a}$, we used the academic learning outcome as the dependent variable with the experiential learning group and volunteer group as the two independent factors. Table 5 indicate a significant model $\left(F_{(3,129)}=43.999 ; p<0.000\right)$. The results also indicate significant main effects of experiential learning group $(\mathrm{F}-\mathrm{value}=59.824 ; \mathrm{p}<0.000)$ and volunteer motivation group ( $\mathrm{F}$-value $=21.973 ; \mathrm{p}<0.000)$, and the interaction effect $(\mathrm{F}$-value $=5.558$; $\mathrm{p}<0.020$; significant) as well. Thus, both H1a and $\mathrm{H} 2 \mathrm{a}$ were supported.

Following the same statistical analysis, we used the career development outcome as the dependent variable with the experiential learning group and volunteer group as the two independent factors in an ANOVA analysis to test $\mathrm{H} 1 \mathrm{~b}$ and $\mathrm{H} 2 \mathrm{~b}$. Table 5 reveals a significant model $\left(\mathrm{F}_{(3,129)}=24.8 ; \mathrm{p}<0.000\right)$. The results also indicate significant main effects of experiential learning group $(F-v a l u e=29.636 ; p<0.000)$ and volunteer motivation group $(\mathrm{F}$-value $=15.401 ; \mathrm{p}<0.000)$, but no significant interaction effect $(\mathrm{F}-\mathrm{value}=$ $0.785 ; \mathrm{p}<0.377$ ). Thus, both $\mathrm{H} 2 \mathrm{~b}$ and $\mathrm{H} 2 \mathrm{~b}$ were supported. With regard to personal growth as the dependent variable, the ANOVA results indicate a significant model $\left(\mathrm{F}_{(3,129)}=22.065 ; \mathrm{p}<0.000\right)$ with significant main effects of the experiential learning group $(\mathrm{F}$-value $=22.103 ; \mathrm{p}<0.000)$ and volunteer motivation group $(F$-value $=18.013 ; p<0.000)$, but no interaction effect $(F-v a l u e=0.165 ; p<0.685)$. Thus, both $\mathrm{H} 1 \mathrm{c}$ and $\mathrm{H} 2 \mathrm{c}$ were supported. To test civic responsibility outcome, the ANOVA results indicate a significant model $\left(\mathrm{F}_{(3,129)}=22.184 ; \mathrm{p}<0.000\right)$ with significant main effects of experiential learning group 
$(\mathrm{F}-\mathrm{value}=17.481 ; \mathrm{p}<0.000)$ and volunteer motivation group $(\mathrm{F}-\mathrm{value}=23.132 ; \mathrm{p}<0.000)$, with no interaction effect $(\mathrm{F}$-value $=2.334 ; \mathrm{p}<0.129)$. Both $\mathrm{H} 1 \mathrm{~d}$ and $\mathrm{H} 2 \mathrm{~d}$ were supported.

Table 6 displays the main effects of experiential learning and volunteer motivation on each servicelearning outcome. The differences between high and low groups of experiential learning on all SL outcomes were statistically significant. Similarly, the differences between high and low groups of volunteer motivation on all SL outcomes were statistically significant. Both $\mathrm{H} 1$ and $\mathrm{H} 2$ were supported.

TABLE 6 MAIN EFFECTS OF EXPERIENTIAL LEARNING AND VOLUNTEER MOTIVATION

\begin{tabular}{|c|c|c|c|c|c|c|c|c|}
\hline \multirow{3}{*}{$\begin{array}{l}\text { Dependent } \\
\text { Variables }\end{array}$} & \multicolumn{4}{|c|}{ Experiential Learning Value } & \multicolumn{4}{|c|}{ Volunteer Motivation } \\
\hline & Low & High & & & Low & High & & \\
\hline & $\begin{array}{l}\text { Group } \\
n=48\end{array}$ & $\begin{array}{c}\text { Group } \\
n=85\end{array}$ & Diff & $\mathrm{Sig}$ & Group & $\begin{array}{c}\text { Group } \\
n=71\end{array}$ & Diff & $\mathrm{Sio}$ \\
\hline $\begin{array}{l}\text { Academic } \\
\text { Outcomes }\end{array}$ & $\begin{array}{l}5.231 \\
(.114)\end{array}$ & $\begin{array}{l}6.319 \\
(.083)\end{array}$ & 1.088 & $.000 *$ & $\begin{array}{l}5.445 \\
(.091)\end{array}$ & $\begin{array}{l}6.104 \\
(.107)\end{array}$ & 0.659 & $.000 *$ \\
\hline $\begin{array}{l}\text { Career } \\
\text { Related } \\
\text { Outcomes }\end{array}$ & $\begin{array}{l}5.20 \\
(.133)\end{array}$ & $\begin{array}{l}6.095 \\
(.097)\end{array}$ & 0.896 & $.000 *$ & $\begin{array}{l}5.325 \\
(.107)\end{array}$ & $\begin{array}{c}5.97 \\
(.125)\end{array}$ & 0.646 & $.000 *$ \\
\hline $\begin{array}{l}\text { Personal } \\
\text { Development }\end{array}$ & $\begin{array}{l}5.011 \\
(.137)\end{array}$ & $\begin{array}{l}5.807 \\
(099)\end{array}$ & 0.796 & $.000^{*}$ & $\begin{array}{l}5.05 \\
(.110)\end{array}$ & $\begin{array}{l}5.768 \\
(.129)\end{array}$ & 0.718 & $.000 *$ \\
\hline $\begin{array}{l}\text { Civic } \\
\text { Responsibility }\end{array}$ & $\begin{array}{l}5.568 \\
(.115)\end{array}$ & $\begin{array}{l}6.162 \\
(.084)\end{array}$ & 0.594 & $.000^{*}$ & $\begin{array}{l}5.523 \\
(.092)\end{array}$ & $\begin{array}{l}6.206 \\
(.108)\end{array}$ & 0.683 & $.000 *$ \\
\hline
\end{tabular}

\section{STUDY\#2}

The second study was conducted in a different semester to compare these three constructs between SL classes and non-SL classes in the same course. At the same university, all students enrolled in the four sections of the Consumer Behavior course were invited to fill out the same online survey as the previous study about their class project experience at the end of the semester. The two sections with a SL project were taught by Professor A again with the same guidelines to select a SL partner and to design experiential learning activities. Another two sections taught by a different faculty member (Professor B) were non-SL classes as there was no requirement for students to volunteer for any community partners. In this non-SL classes, Professor B used traditional lecture method with few student individual assignments.

A total of 108 undergraduates voluntarily participated in this research. About $87 \%$ of the respondents were $20-22$ years old, $62 \%$ were females, and $94 \%$ were marketing majors. Approximately $44 \%$ were juniors and $50 \%$ were seniors. About $65.7 \%$ of the respondents were in the SL group and $34.3 \%$ of them in the non-SL group. The $2^{\text {nd }}$ study used the same measures and subscales. The scale validity of each construct had been tested in the first study. In Table 2, all the Cronbach alpha coefficients for each subscale and construct were higher than the minimum requirement of 0.7 (Nunnally, 1978).

By using one-way ANOVA, each subscale (dependent variable) of the three constructs was compared between the SL and non-SL groups. Table 7 indicates that the SL group had a higher level of civic responsibility than the non-SL group $\left(\mathrm{Mean}_{\mathrm{SL}}=5.24>\mathrm{Mean}_{\mathrm{NSL}}=4.71 ; \mathrm{F}_{(1,106)}=4.866, \mathrm{p}<.030\right)$. This result once again support that SL pedagogy may enhance student's civic responsibility. Interestingly, it seems that SL pedagogy may also encourage students' volunteer motivation as the SL group had higher levels on all the subscales of volunteer motivation at the 0.1 significant level (career Mean $_{\mathrm{SL}}=5.61>$ Mean $_{N S L}=5.05$; understanding $\operatorname{Mean}_{\mathrm{SL}}=5.91>\operatorname{Mean}_{\mathrm{NSL}}=5.39$; values $\operatorname{Mean}_{\mathrm{SL}}=5.92>\operatorname{Mean}_{\mathrm{NSL}}=5.48$; 
protective $\operatorname{Mean}_{\mathrm{SL}}=4.89>\quad$ Mean $_{\mathrm{NSL}}=4.41 ; \quad$ social $\quad \operatorname{Mean}_{\mathrm{SL}}=4.62>\quad \operatorname{Mean}_{\mathrm{NSL}}=5.16$; enhancement Mean $_{\mathrm{SL}}=5.47>\mathrm{Mean}_{\mathrm{NSL}}=4.90$ ).

Nevertheless, no significant differences in experiential learning were found between SL and non-SL groups. The results imply that non-SL classes are not necessarily low in experiential learning. SL pedagogy is only one of many experiential learning approaches. Instructors can still use other experiential approaches to enrich student learning experiences.

TABLE 7

ANOVA: DIFFERENCE BETWEEN NON-SL AND SL GROUPS

\begin{tabular}{|l|c|c|c|c|}
\hline Dependent Variables & $\begin{array}{c}\text { Non-SL group } \\
(\mathrm{n}=37) \\
\text { Mean }\end{array}$ & $\begin{array}{c}\text { SL group } \\
(\mathrm{n}=71) \\
\text { Mean }\end{array}$ & $\mathrm{F}(1,106)$ & Sig. \\
\hline Service-Learning Outcomes & & & & \\
\hline Career outcomes & 4.88 & 5.14 & 1.076 & .302 \\
\hline Academic outcomes & 5.41 & 5.48 & .097 & .756 \\
\hline Personal outcomes & 5.04 & 5.18 & .420 & .518 \\
\hline Civic responsibility & 4.71 & 5.24 & 4.866 & $.030^{* *}$ \\
\hline Experiential Learning & & & & \\
\hline Concrete experience & 5.68 & 5.77 & .198 & .658 \\
\hline Reflection observation & 5.49 & 5.34 & .319 & .574 \\
\hline Abstract conceptualization & 5.61 & 5.44 & .696 & .406 \\
\hline Active experimentation & 5.55 & 5.56 & .002 & .968 \\
\hline Volunteer Motivation & & & & \\
\hline Career & 5.05 & 5.61 & 5.558 & $.020^{* *}$ \\
\hline Understanding & 5.39 & 5.91 & 5.958 & $.016^{* *}$ \\
\hline Values & 5.48 & 5.92 & 3.795 & $.054^{*}$ \\
\hline Protective & 4.41 & 4.89 & 2.889 & $.092^{*}$ \\
\hline Social & 4.62 & 5.16 & 5.043 & $.027^{* *}$ \\
\hline Enhancement & 4.90 & 5.47 & 4.924 & $.029^{* *}$ \\
\hline
\end{tabular}

Note: ${ }^{* *}$ Significant at the level of $0.05 ; *$ Significant at the level of 0.10

\section{DISCUSSION}

The current research addresses how to create high level of experiential learning experiences as they are essential for the success of SL pedagogy (Petkus 2000). Although many scholars at the higher education advocate for integrating Kolb's experiential learning cycle in a SL course design (Petkus 2000; Wang and Calvano 2018), no research in business education has demonstrated how to do it. This study presents the guidelines for the selection of a SL partner and the design of experiential learning activities for a SL course. It also demonstrates how to integrate Kolb's theory and how to create experiential activities for each stage of the learning cycle in a Consumer Behavior SL course.

First, we offer suggestions on how to find and select SL partners. Not all nonprofit organizations are the right SL partners. Two criteria are (1) the fit between the course learning objectives and a SL partner's goals, and (2) the cooperation from the SL partners. This field study illustrated the process to find the right SL organizations and how to outline the responsibilities for SL partners in a marketing course. With regard to the design of experiential learning activities in Kolb's learning cycle, Table 1 summarizes the guidelines as (1) the role of each stage, (2) the list of experiential activities on each stage and (3) what student knowledge may be created through the transformation of these experiential activities. This field study used many experiential activities involved at the experiencing, thinking, acting and reflecting stages. In this study, the average level of all students' perceptions of experiential learning is 5.87 on a 7- 
point scale. Thus, we recommend these guidelines and examples of experiential activities to business faculty as a strategy to develop high experiential learning for SL courses.

This research examined the effects of experiential learning and volunteer motivation in SL courses on undergraduates' learning outcomes. Overall, this field study supported all the research hypotheses. There are main effects of experiential learning and volunteer motivation in SL courses on student learning outcomes. Students who perceive a high level of experiential learning toward a SL course report more favorable learning outcomes on career, academic, personal growth, and civic responsibility than those who perceive a low level of experiential learning. This study also reveals that students respond to "mandatory volunteerism" on the same SL courses differently, and they have different levels of volunteer motivation. Students who have a high level of volunteer motivation report more favorable SL learning outcomes than those who have a low level of volunteer motivation.

To better understand students' differences and future intentions to volunteer, we used Study\#1 and further classified our student respondents into four groups ( 2 high/low experiential learning X 2 high/low volunteer motivation). One survey question "I will be more likely to volunteer at the community agency of the project" was used to measure student "future intention to volunteer." Table 8 displays the statistics (mean and standard deviation) of these dependent variables for each group. We ran multiple comparison analyses between these groups. The statistical results indicate that Group\#1 had significantly lower responses on learning outcomes and future intention to volunteer, compared to those in Group\#2, \#3, and \#4. Group\#1 are students who have low volunteer motivation and perceive a low level of experiential learning and might be the only segment who do not respond to SL pedagogy favorably. It seems that SL pedagogy may still work well for students in other groups (\#2, \#3, and \#4) who may have high level of volunteer motivation, and/or perceive a high level of experiential learning. Especially, for students who have low volunteer motivation, this study demonstrated that their learning outcomes can be significantly improved if the SL course is designed for these students to perceive a high level of experiential learning (Group\#2).

\section{TABLE 8 GROUP DIFFERENCES ON STUDENT LEARNING OUTCOMES \& FUTURE INTENTION TO VOLUNTEER}

\begin{tabular}{|l|cc|cc|}
\hline \multirow{5}{*}{ Dependent Variables } & \multicolumn{2}{|c|}{$\begin{array}{c}\text { Low } \\
\text { Volunteer Motivation (vm) }\end{array}$} & \multicolumn{2}{c|}{$\begin{array}{c}\text { High } \\
\text { Volunteer Motivation (vm) }\end{array}$} \\
\cline { 2 - 5 } & $\begin{array}{c}\text { Group\#1 } \\
\text { Low } \\
\text { Experiential } \\
\text { Learning } \\
(\exp )(\mathrm{n}=34)\end{array}$ & $\begin{array}{c}\text { Group\#2 } \\
\text { High Experiential } \\
\text { Learning (exp) } \\
(\mathrm{n}=28)\end{array}$ & $\begin{array}{c}\text { Group\#3 } \\
\text { Low } \\
\text { Experiential } \\
\text { Learning (exp) } \\
(\mathrm{n}=14)\end{array}$ & $\begin{array}{c}\text { Group\#4 } \\
\text { High } \\
\text { Experiential } \\
\text { Learning (exp) } \\
(\mathrm{n}=57)\end{array}$ \\
\hline Academic Learning Outcome & $4.74(1.10)$ & $6.15(.52)$ & $5.73(.81)$ & $6.48(.43)$ \\
\hline Career Outcome & $4.80(1.25)$ & $5.85(.79)$ & $5.60(.73)$ & $6.35(.52)$ \\
\hline Personal Growth & $4.62(1.17)$ & $5.48(.75)$ & $5.40(.82)$ & $6.13(.69)$ \\
\hline Civic Responsibility & $5.12(1.09)$ & $5.93(.62)$ & $6.02(.57)$ & $6.40(.50)$ \\
\hline Future Intention to Volunteer & $4.44(1.62)$ & $5.21(1.17)$ & $5.43(1.09)$ & $6.04(1.02)$ \\
\hline
\end{tabular}

All Measures: 7-point scale; mean (standard error)

How do students perceive a high level of experiential learning? Students learning strategies may influence their perceptions on high or low levels of experiential learning for the same SL course design. Young et al.'s (2008) found that experiential learning activities that incorporate all stages of the learning cycle were positively related to students with a deep approach to learning. To benefit students learning, students should encourage themselves to engage in a deep approach to learning, where they focus on the underlying purpose and meaning of the learning process. 
Due to the undesirable impact of mandatory volunteerism in SL pedagogy, Stukas et al. (1999) suggest that schools give students a sense of freedom and autonomy to design their service experiences. Other recommendations are to offer volunteer service as an option, instead of a requirement (Kretchmar, 2001; Lundy, 2007). However, some students, especially those with low volunteer motivation, probably would choose not to engage in any community service at all. This study offers another suggestion. A high experiential learning course could be an effective strategy to help these students with low volunteer motivation.

Our Study\#2 compared the SL group with the non-SL group on students' learning outcomes, volunteer motivation, and perceptions of experiential learning. With regard to civic responsibility, our study result was consistent with the previous findings that students in the SL group had a higher level than their counterparts. A surprising finding was that students in the SL group also had higher levels on all the subscales of volunteer motivation. This finding implies the potential benefits of SL pedagogy to enhance students' volunteer motivation.

Study\#2 included the non-SL group as a control group but didn't find any significant differences in students' perceptions of experiential learning between the two groups. The results support that a variety of approaches can be used to enrich the student learning experience, not only just SL pedagogy. Kolb (1984) defines experiential learning approaches as a process whereby knowledge is created through the transformation of experience. Many teaching methods are experiential learning approaches, such as cases, simulation, business consulting, or SL projects (Young et al. 2008). All these experiential learning approaches are rooted in Kolb's (1984) experiential learning theory (Young et al. 2008). SL is one of many experiential learning approaches. As we know, no research suggests if SL has highest levels of experiential learning among all experiential learning approaches. This could be topic for future research.

A concern raised about SL pedagogy is its ethicaityl as it forces students to do SL projects. Developing college students' social responsibility and civic engagement with their community has been a central goal of higher education (Antonio, Auastin, \& Cress, 2000). Thus, in higher education, we have the responsibility to help students with civic engagement. Extensive research recommends SL pedagogy as an impactful teaching approach to develop students' civic responsibility. Also, it helps students achieve other learning outcomes, such as career, academic or personal growth (e.g., Geringer et al. 2009; Wang and Calvano 2018). Instructors use a variety of teaching methods that are designed to help students achieve learning objectives. For example, students are "forced" to do assignments or to take exams for their own benefits and learning outcomes. Likewise, SL pedagogy with mandatory volunteerism is an effective method to benefit students to develop their civic responsibilities and engagement.

This research demonstrated the extensive process to develop a SL course. Given the time and efforts required in the process, why would faculty adopt SL pedagogy? Students prefer to volunteer when the activity is related to their interests or majors (Garver et al. 2009). SL pedagogy is an effective strategy to help students develop civic responsibility. If no SL courses are offered at higher education institutions, how would educators help students develop civic responsibility? To encourage faculty to use SL pedagogy, future research should explore the resources or support that higher education institutions can use to encourage faculty develop and teach SL courses.

\section{LIMITATIONS}

There are several limitations of this research. First, our respondents were recruited from marketing courses taught by the same instructor in a public university. All our participants are business undergraduate students. The results cannot be generalized to majors outside of business, or types of schools at the higher education. Some majors, such as social work or nursing, are more involved in social needs and might have a higher level of volunteer motivation than business students. They may respond to SL pedagogy differently. Future research should be conducted in different majors or school settings.

Additionally, this study did not investigate if SL pedagogy can increase volunteer motivation, or to evaluate the magnitude of contribution to student learning outcomes. Future research should survey students before and after their SL experience to explore these effects of SL pedagogy. This study found that volunteer motivation plays an important role in student learning. High levels of volunteer motivation 
are associated with intrinsic motives. Future research may explore how to increase intrinsic motivations to volunteer for college students.

\section{REFERENCES}

Antonio, A.L., Astin, H.S., \& Cress, C.M. (2000). Community Service in Higher Education: A Look at the Nation's Faculty. The Review of Higher Education, 23(4), 373-398

Bacon, D.R., \& Stewart, K.A. (2006). How Fast Do Students Forget What They Learn in consumer

Behavior? A Longitudinal Study. Journal of Marketing Education, 28(3), 181-92.

Beehr, T. A., LeGro, K., Porter, K., Bowling, N. A., \& Swader, W. M. (2010). Required Volunteers: Community Volunteerism among Students in College Classes. Teaching of Psychology, 37(4), 276-280.

Berry, G. R., \& Workman, L. (2007). Broadening student societal awareness through service-learning and civic engagement. Marketing Education Review, 17(3), 21-32.

Brehm, S.S., \& Brehm, J. (1981). Psychological reactance: A Theory of freedom and control. New York: Academic Press

Bringle, R. G., \& Hatcher, J. A. (2000). Meaningful measurement of theory-based service-learning outcomes: Making the case with quantitative research. Michigan Journal of Community Service Learning, pp. 68-75.

Burns, D. J. (2011, Summer). Motivations to Volunteer and Benefits from Service Learning. Journal for Advancement of Marketing Education, 18, 10-23.

Bussell, H., \& Forbes, D. (2002). Understanding the volunteer market: The what, where, who and why of volunteering. The International Journal of Nonprofit and Voluntary Sector, 7(3), 244-257.

Cadwallader, S., Atwong, C., \& Lebard, A. (2013). Proposing Community-Based Learning in the Marketing Curriculum. Marketing Education Review, 23(2), 137-150.

Clary, E. G., Snyder, M., \& Stukas, A.A. (1998). Service-learning and psychology: Lessons from the psychology of volunteers' motivations. In R.G. Bringle \& D. K. Duffy (Eds.), With service in mind: Concepts and Models for Service-Learning in Psychology (pp. 35-50). Washington, DC: American Association of Higher Education

Clary, E. G., Snyder, M., Ridge, R. D., Copeland, J., Stukas, A. A., Haugen, J., \& Miene, P. (1998). Understanding and assessing the motivations of volunteers: A functional approach. Journal of Personality and Social Psychology, 74(6), 1516-1530.

Dewey, J. (1933). How We Think. Boston: Houghton Mifflin.

Fornell, C., \& Larcker, D. (1981). Structural Equation Models With Unobservable Variables and Measurement Error: Algebra and Statistics. Journal of Marketing Research, 18(3), 382-388.

Furco, A. (1996). Service-learning: a balanced approach to experiential education. In B. Taylor \& Corporation for National Service (Eds.), Expanding Boundaries: Serving and Learning (pp. 2-6). Washington, DC: Corporation for National Service.

Garver, M., Divine, R., \& Spralls, S. (2009). Segmentation Analysis of the Volunteering Preferences of University Students. Journal of Nonprofit \& Public Sector Marketing, 21(1), 1-23.

Geringer, S. D., Stratemeyer, A. W., Canton, A., \& Rice, W. (2009). Assessing service-learning outcomes in a principles of marketing course: A team-based vs. individual-based approach. Journal for Advancement of Marketing Education, 14, 1-11.

Godfrey, P. C., \& Berry, G. R. (2005). Creating breadth in business education through service-learning. Academy of Management Learning \& Education, 4(3), 309-32.

Gonzalez-Padron, T., \& Ferguson, J. M. (2015). Using a service audit project for improving student leaning in a service-marketing course. Marketing Education Review, 25(2), 99-116.

Gottlieb, K., \& Gibson, G. (2006). A Practical Guide for Integrating Civic Responsibility into Curriculum (The 2nd edition). Community College Press: Washington DC. Retrieved March 27, 2020, from https://files.eric.ed.gov/fulltext/ED509538.pdf

Hagenbuch, D. J. (2006). Service-learning inputs and outcomes in a personal selling course. Journal of Marketing Education, 28(1) 26-34. 
Hair, J., Black, W., Babin, B., \& Anderson, R., (2010). Multivariate data analysis (7th ed.). Upper Saddle River, NJ: Prentice-Hall, Inc.

Hatcher, J.A., \& Bringle, R.G. (2000). Reflection: Bridging the gap between service and learning. College Teaching, 45(4), 153-58.

Hustinx, L. Vanhove, T., Declercq, A., Hermans, K., \& Lammertyn, F. (2005). Bifurcated Commitment, Priorities, and Social Contagion: The Dynamics and Correlates of Volunteering within a University Student Population. British Journal of Sociology of Education, 26(4), 523-538.

Jacoby, B. (2014). Service-learning essentials: Questions, answers, and lessons learned. John Wiley \& Sons.

Klink, R. R., \& Athaide, G.A. (2004). Implementing service learning in the principles of marketing course. Journal of Marketing Education, 26(2), 145-53.

Kolb, D. A. (1984). Experiential Learning: Experience as the Source of Learning and Development. Englewood Cliffs, NJ: Prentice Hall.

Krebs, D. L., \& Miller, D. T. (1985). Altruism and aggression. In G. Lindzey and E. Aronson (Eds). Handbook of social psychology (3rd ed., Vol. 2, pp. 1-71). New York: Random House.

Kretchmar, M. D. (2001). Service Learning in a General Psychology Class: Description, Preliminary Evaluation, and Recommendations. Teaching of Psychology, 28(1), 5-10.

LeCair, D.T., \& Stottinger, B. (1999). Using an Intensive Living Case in Graduate Marketing Courses: Experiences from an International Project. Marketing Education Review, 9(3), 31-40.

Lester, S.W., Tomkovikc, C., Wells, T., Flunker, L., \& Kickul, J. (2005). Does service-learning add value? Examining the perspectives of multiple stakeholders. Academy of Management Learning and Education, 4(3), 278-294.

Lundy, B. (2007). Service Learning in Life-Span Developmental Psychology: Higher Exam Scores and Increased Empathy. Teaching of Psychology, 34(1), 23-27.

Maghsudlu, M., \& Nasizadeh, S. (2011). Iranian blood donors' motivations and their influencing factors. Transfusion Medicine, 21(4), 247-252.

Marks, H. M., \& Jones, S.R. (2004). Community Service in the Transition: Shifts and Continuities in Participation from High School to College. Journal of Higher Education, 75(3), 307.

Nunnally, J. C. (1978). Psychometric theory (2nd ed.). New York: McGraw-Hill.

Penner, L. A. (2004). Volunteerism and social problems: Making things better or worse? Journal of Social Issues, 60, 645-666.

Peterson, D. K. (2004). Recruitment strategies for encouraging participation in corporate volunteer programs. Journal of Business Ethics, 49(4), 371.

Petkus, E., Jr. (2000). A theoretical and practical framework for service-learning in marketing: Kolb's experiential learning cycle. Journal of Marketing Education, 22(1) 64-70.

Piliavin, J.A., \& Callero, P. L. (1991). Giving blood: The development of an altruistic identify. Baltimore: Johns Hopkins University Press

Stukas, A.A., Snyder, M., \& Clary, E.G. (1999). The effects of "mandatory volunteerism" on intentions to volunteer. Psychological Science, 10, 59-64.

Tomkovick, C., Lester, S., Flunker, L., \& Wells, T. (2008). Linking collegiate service-learning to future volunteerism: Implications for nonprofit organizations. Nonprofit Management and Leadership, 19(1), 3-26.

Wang, L., \& Calvano, L. (2018). Understanding how service-learning pedagogy impacts student learning objectives. Journal of Education for Business, 93(5), 204-212

Wymer ,W. W., Jr. (2003). Differentiating literacy volunteer: A segmentation analysis for target marketing. International Journal of Nonprofit and Voluntary Sector Marketing, 8(3), 267.

Yorio, P.L., \& Ye, F. (2011). A meta-analysis on the effects of service-learning on the social, personal, and cognitive outcomes of learning. Academy of Management Learning \& Education, 11(1), 927.

Young, M. R., Caudill, E. M., \& William, M. J. (2008). Evaluating experiential learning activities. Journal for Advancement of Marketing Education, 13, 28-40. 